(2) Open Access Full Text Article

ORIGINAL RESEARCH

\title{
Improved Interchangeability with Different Corneal Specular Microscopes for Quantitative Endothelial Cell Analysis
}

This article was published in the following Dove Press journal:

Clinical Ophthalmology

\author{
Gwyneth A van Rijn (1D' \\ C Jasper F Wijnen' \\ Bart TH van Dooren $\mathbb{D D}^{2,3}$ \\ Yanny YY Cheng' \\ Jan-Willem M Beenakker $\mathbb{D}^{1,4}$ \\ Gregorius PM Luyten (D) \\ 'Department of Ophthalmology, Leiden \\ University Medical Center, Leiden, The \\ Netherlands; ' ${ }^{2}$ Department of \\ Ophthalmology, Erasmus Medical Center, \\ Rotterdam, The Netherlands; \\ ${ }^{3}$ Department of Ophthalmology, Amphia \\ Medical Hospital, Breda, The \\ Netherlands; ${ }^{4}$ C.J.Gorter Center for \\ High Field MRI, Department of Radiology, \\ Leiden University Medical Center, Leiden, \\ The Netherlands
}

Correspondence: Gwyneth A van Rijn Department of Ophthalmology, Leiden University Medical Center, Leiden, The Netherlands

Email g.a.van_rijn@lumc.nl
Introduction: During our clinical practice and research, we encountered an interchangeability problem when using the SP-2000P and SP-3000P TopCon corneal specular microscopes (CSMs) (TopCon Medical Systems, Tokyo, Japan) regarding the endothelial cell count (ECC). We describe a method to improve interchangeability between these CSMs.

Methods: Five consecutive good-quality endothelial cell photographs were obtained in 22 eyes of 11 subjects. An ECC comparison between the two CSMs was performed after (I) gauging and calibration by the manufacturer, (II) adjustment of the magnification, (III) correction after external horizontal and vertical calibration.

Results: There was a statistically significant difference between the ECC of the SP-2000P and SP-3000P at the start. The SP-2000P counted an average of 500 cells $/ \mathrm{mm}^{2}$ more than the SP-3000P $(\mathrm{p}=0.00)$. After correction for magnification and determining a correction factor based on external calibration, the difference between the ECC of the SP-2000P and the SP$3000 \mathrm{P}$ was then found to be 0.4 cells $/ \mathrm{mm}^{2}$ and was not statistically significant $(\mathrm{p}=0.98)$.

Discussion: We propose a method for improving interchangeability, which involves checking magnification settings, re-checking magnification calibration with external calibration devices, and then calculating correction factors. This method can be applied to various specular or confocal microscopes and their associated endothelial cell analysis software packages to be able to keep performing precise endothelial cell counts and to enable comparison of ECCs when a CSM needs to be replaced or when results from different microscopes need to be compared.

Keywords: corneal endothelium, corneal endothelial cells, specular microscopy, endothelial cell count, endothelial cell density, corneal endothelial cell analysis

\section{Introduction}

Corneal specular microscopy (CSM) can provide non-invasive quantitative and qualitative analysis of the most inner layer of the cornea, the endothelium. Specular reflection refers to the viewing of objects that occurs when light is reflected from the interfaces of materials with different refractive indices. A specular microscope (SM) captures the image that is reflected from the optical interface between the corneal endothelium and the aqueous humor. The endothelial cells (ECs) can be imaged because the refractive index of the ECs exceeds the refractive index of the aqueous humor. ${ }^{1}$ When the angle of incident light equals the angle of reflection, an image occurs in a mirror-like fashion and can be captured by the eye or a camera. This principle was first described by Vogt in $1920 .^{2}$ 
In the modern specular microscopic endothelial analysis, software is responsible for quantitative EC analysis. This is also referred to as endothelial cell density (ECD) or endothelial cell count (ECC) in cells per square millimeter (cells/ $\mathrm{mm}^{2}$ ). The only way for the software to correctly assess the ECC is when it is attached to only one adequately calibrated and gauged CSM. This is important since every individual CSM has its own magnification and calibration settings.

Various specular microscopes have been developed by a number of companies. Different CSMs and image analysis methods have been evaluated for comparability and are usually not interchangeable. ${ }^{3-8}$ To be able to reliably compare longitudinal ECC measurements, it is therefore wise to use the same CSM and analysis system for all measurements. However, when instruments wear out, it is often no longer possible or even desirable to replace it with the same previous type. This may pose a problem, as we discovered when we needed to replace the old CSM at our department. Although we selected its newer version, manufactured by the same company, we still encountered an interchangeability issue.

Amongst other indications, the CSM is actively used at our department to evaluate the corneal endothelium for pre-operative assessment and follow-up visits after implantation of irisfixated phakic intraocular lenses (IF-pIOL). Evaluation of the corneal endothelium is a key safety parameter after implantation of IF-pIOL and other anterior chamber pIOLs. Since quantitative EC analysis is the most accepted and commonly used parameter for evaluating the corneal endothelium after various types of intraocular surgery and there is a need for reliable ECCs to assess the long-term safety, ${ }^{9-12}$ we would like to propose an effective way to deal with interchangeability concerns arising from the use of different types of CSMs, such as when an instrument needs to be replaced.

\section{Methods}

We will describe the method used for comparing two individual CSMs in the SP-series of Topcon (Topcon Medical Systems, Tokyo, Japan): our newer SP-3000P model and our older SP-2000P model.

With each specular microscope, five consecutive goodquality endothelial cell photographs were obtained in 22 eyes of 11 subjects. In accordance with the Declaration of Helsinki and approval of the medical ethical committee of the Leiden University Medical Center, each participating patient signed an informed consent form. Photographs of the central corneal ECs were acquired by one experienced operator. ECCs were determined by semi-automated "corrected endothelial cell count" using the IMAGEnet software, i.e. the software- defined cell borders were manually corrected prior to quantitative calculations (also known as re-traced method) as described by Cheung and Cho. ${ }^{13}$ The maximum possible cell area was selected for semi-automated corrected endothelial cell counts. All ECCs obtained were recorded in a database (Microsoft Excel 2010), and statistics were performed in SPSS (IBM SPSS version 23 for Windows). Mixed models and Bland-Altman plots were used for analysis and graphical visualization of the acquired data.

An ECC comparison between the two CSMs was performed after each of the following steps:

1. Both CSMs were checked, calibrated and gauged by the manufacturer, and the associated Topcon IMAGEnet software was updated to version 3.10.5.

2. Manual adjustment of magnification factor. The "true mask slit width", meaning the distance between the tick marks on an EC photograph, is close to $0.2 \mathrm{~mm}$ but differs in each microscope. The exact individual value can be displayed on the instrument by pressing the "cancel" and "delete" buttons simultaneously before turning it on. The magnification is reported for each endothelial cell image as "pixel size", as shown in Figure 1. Usually, it is set at a default value of 0.00115 , which is the standard, pre-programmed magnification value in the IMAGEnet software assuming a true mask slit of $0.2 \mathrm{~mm}$. To optimally gauge the instrument to its analysis software, the magnification factor was re-calculated using the true mask slit according to the formula: Magnification $=($ True mask slit width $/ 0.2) * 0.00115,{ }^{14,15}$ and, if necessary, the magnification factor was in turn manually adjusted accordingly in the IMAGEnet software, see Appendix. ECCs were subsequently re-analyzed with the re-traced method ("corrected endothelial cell counts") within the IMAGEnet software.

3. External calibration. An external calibration microruler tool was photographed both horizontally and vertically with both CSMs. To obtain a clear photographic image of the calibration micro-ruler, an experimental set-up was created with the micro-ruler positioned where normally the investigated eye would be. To obtain a clear photograph without using the internal flash of the CSM, a filter was placed in front of the CSM and a light source was placed behind the microruler. To minimize distortion effects, the calibration micro-ruler was photographed five times both horizontally and vertically. Photographs were taken by two 


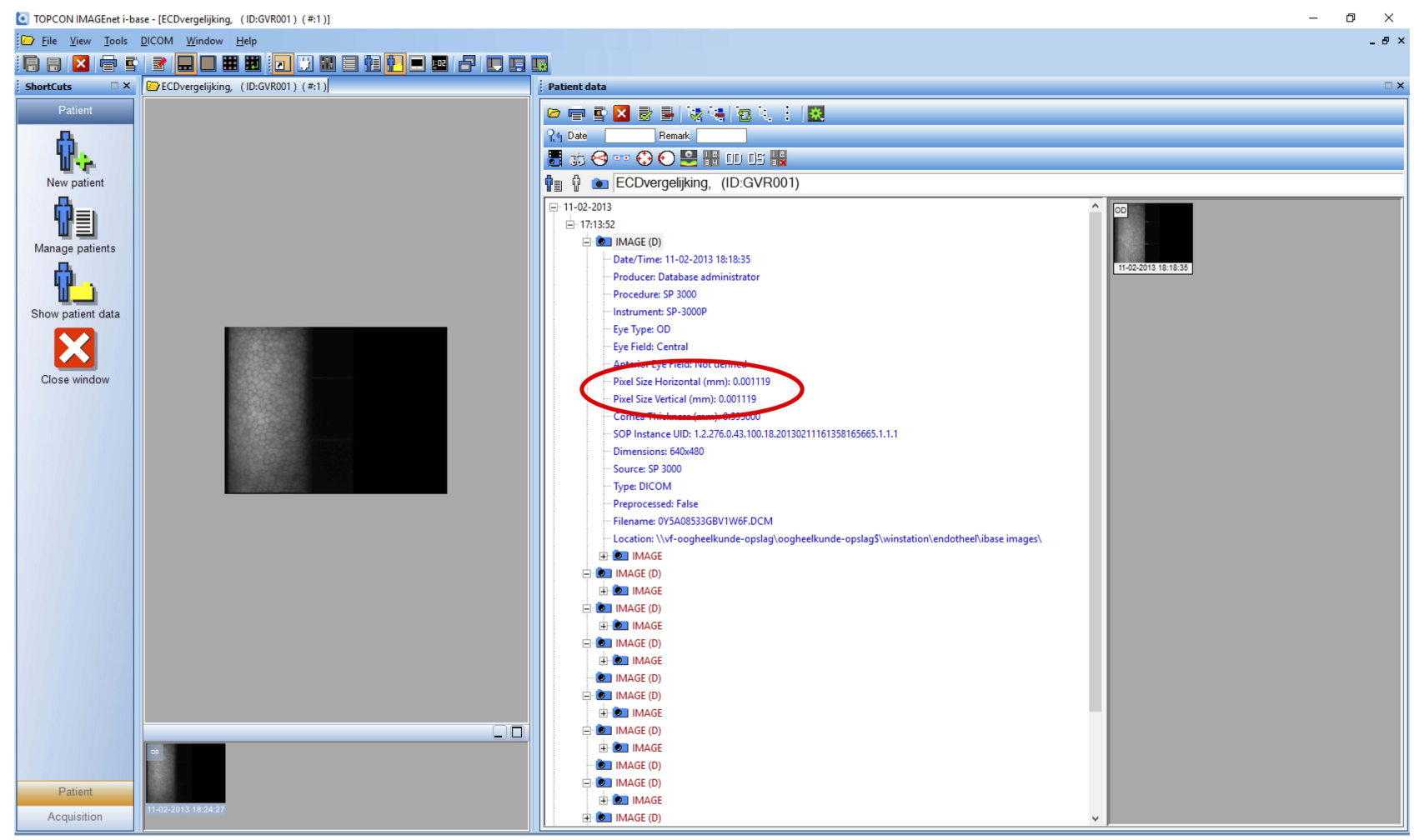

Figure I Print-screen of IMAGEnet software for endothelial cell analysis. The red circle indicates where to find the parameter for magnification referred to as "pixel size".

technicians, each time with a slight positional change of the experimental set-up. Photographs were only taken if the light reflex was or approximated a perfect circle. A minimum of two measurements was
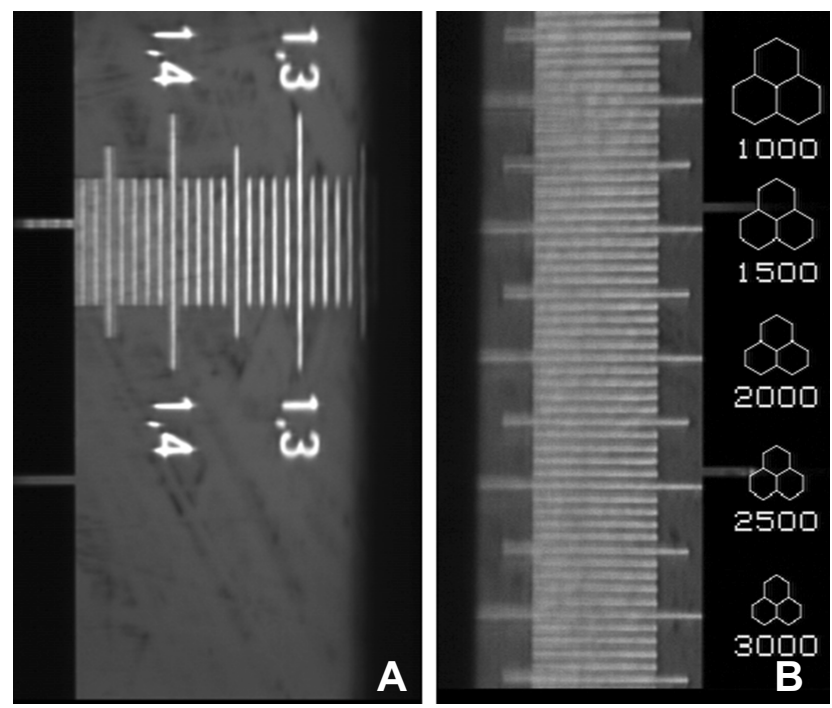

Figure 2 Picture of the micro-ruler used for external calibration, photographed with our specular microscopes. (A) Image of horizontal external calibration made with the SP-3000P. (B) Image of vertical external calibration made with the SP-2000P. performed per photograph and the mean of all measurements was reported as the true distance; see Figure 2.

\section{Results}

1. There was a statistically significant difference between the ECC of the SP-2000P and SP-3000P. The SP-2000P counted an average of 500 cells $/ \mathrm{mm}^{2}$ more than the SP$3000 \mathrm{P}(\mathrm{p}=0.00)$; see Table 1 and Figure 3 .

2. Manual adjustment of magnification factor.

- SP-2000P: The true mask slit width was $0.1891 \mathrm{~mm}$. The magnification was perfectly set to $(0.1891 / 0.2)$ $* 0.00115=0.001087$. In the IMAGEnet software, we discovered that the magnification was set to the factory default 0.00115 and we also encountered a situation where the magnification was not set at all.

- SP-3000P: The true mask slit width was $0.1946 \mathrm{~mm}$. The magnification was perfectly set to $(0.1946 / 0.2)$ $* 0.00115=0.001119$. The magnification was correctly set in the IMAGEnet software.

- After adjusting to the correct pixel size and doing a recount of ECC, a statistically significant difference of 245 cells $/ \mathrm{mm}^{2}(\mathrm{p}=0.00)$ remained between the two CSMs; see Table 2 and Figure 4.

3. External calibration. 
Table I Difference in Endothelial Cell Count per Specular Microscope IMAGEnet

\begin{tabular}{|l|l|l|}
\hline $\begin{array}{l}\text { Specular } \\
\text { Microscope }\end{array}$ & $\begin{array}{l}\text { Mean ECC } \\
\left(\text { Cells } / \mathbf{m m}^{2}\right)\end{array}$ & $\begin{array}{l}\text { Difference }\left(\text { Cells } / \mathbf{m m}^{2}\right) \\
\text { (SD) }(\mathbf{p})\end{array}$ \\
\hline $\begin{array}{l}\text { SP-2000P } \\
\text { SP-3000P }\end{array}$ & 3058.7 & $500.2($ SD I50.4) $(\mathrm{p}<0.05)$ \\
\hline
\end{tabular}

Abbreviations: ECC, endothelial cell count; SD, standard deviation; $p$, significance level linear mixed model.

Based on the horizontal and vertical calibration with the micro-ruler tool, a slight asymmetry was detected between horizontal and vertical measurements. This slight distortion of the cell count area led to an over- or underestimation of the ECC, as shown in Figure 5.

- SP-2000P: An underestimation in the cell count area resulted in an overestimation in ECC of $8.1 \%$.

- SP-3000P: An overestimation in the cell count area resulted in an underestimation in ECC of $1.4 \%$.

A correction factor, based on the remaining difference in surface area after external calibration, was computed for both CSMs, and ECCs were re-determined. The difference between the ECC of the SP-2000P and the SP-3000P was
Table 2 Difference in Endothelial Cell Count per Specular Microscope Corrected for Magnification Factor

\begin{tabular}{|l|l|l|}
\hline $\begin{array}{l}\text { Specular } \\
\text { Microscope }\end{array}$ & $\begin{array}{l}\text { Mean ECC } \\
(\text { Cells/mm } \mathbf{~})\end{array}$ & $\begin{array}{l}\text { Difference (Cells/mm } \mathbf{2}) \\
(\text { SD) }(\mathbf{p})\end{array}$ \\
\hline SP-2000P & 2802.7 & $244.5($ SD II0.9) $(\mathrm{p}<0.05)$ \\
SP-3000P & 2558.2 & \\
\hline
\end{tabular}

Abbreviations: ECC, endothelial cell count; SD, standard deviation; p, significance level linear mixed model.

then found to be 0.4 cells $/ \mathrm{mm}^{2}$ and was not statistically significant $(\mathrm{p}=0.98)$; see Table 3 and Figure 6 .

\section{Discussion}

Various authors describe that different types of CSMs, manufactured by different companies, are not interchangeable. ${ }^{3-8,16}$ During our clinical practice and research, we also encountered an interchangeability problem when using different CSMs. In our research involving longitudinal ECC analysis after Artisan IF-pIOLs, we discovered a significant difference in ECCs when we replaced our "old" SP-2000P CMS with the newer SP-3000P version; see Figure 7. In this paper, we discuss an interchangeability problem between two CSMs, the Topcon SP-2000P and SP-3000P, manufactured by the same company (Topcon Medical Systems). The interchangeability concern in

Bland Altman plot of corrected semi-automated endothelial cell counts in IMAGEnet

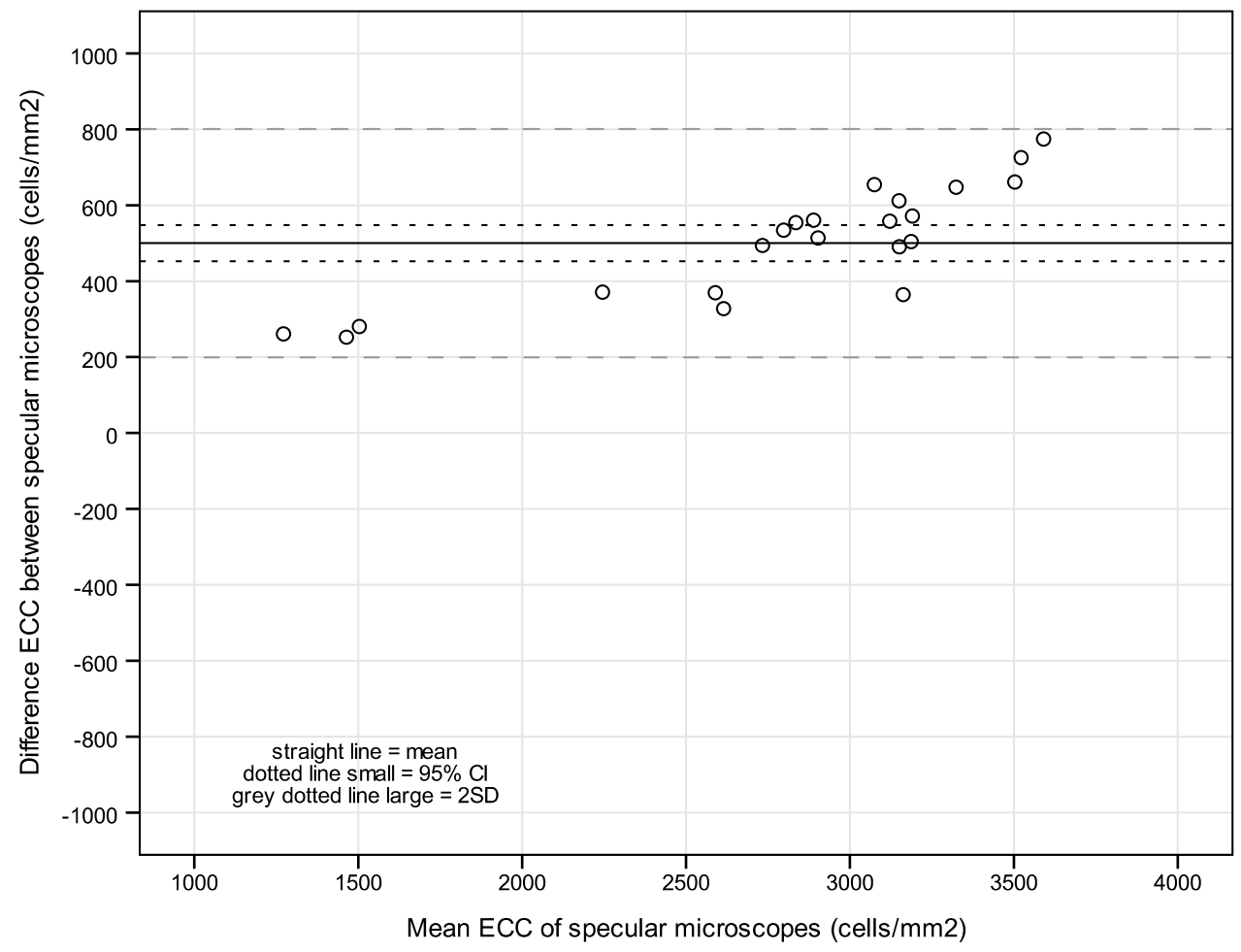

Figure 3 Bland-Altman plot of corrected endothelial cell counts (re-traced method) in IMAGEnet. 
Bland Altman plot endothelial cell count after correction of magnification factor

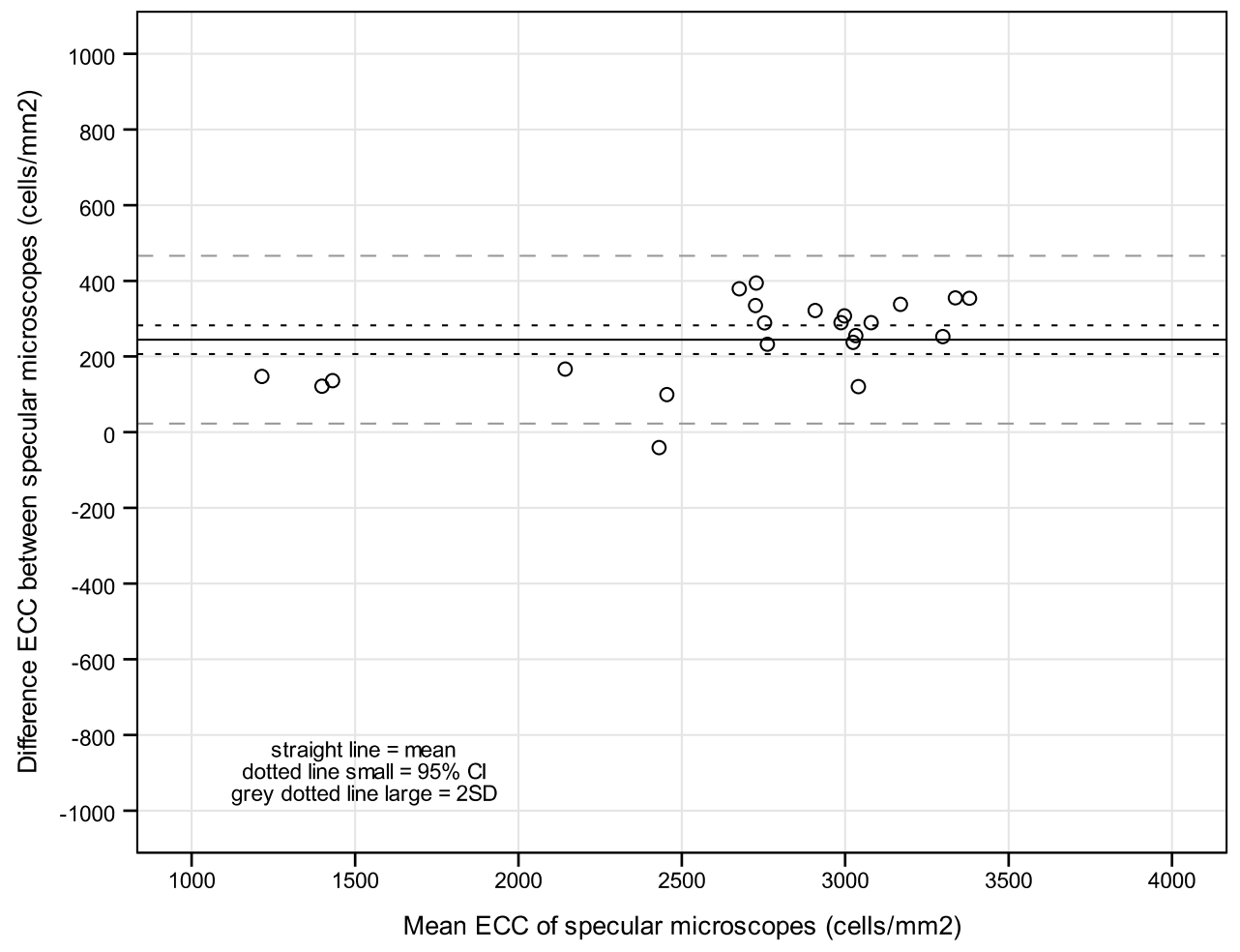

Figure 4 Bland-Altman plot of endothelial cell count after correction of magnification factor.

Bland Altman plot of endothelial cell count after external calibration

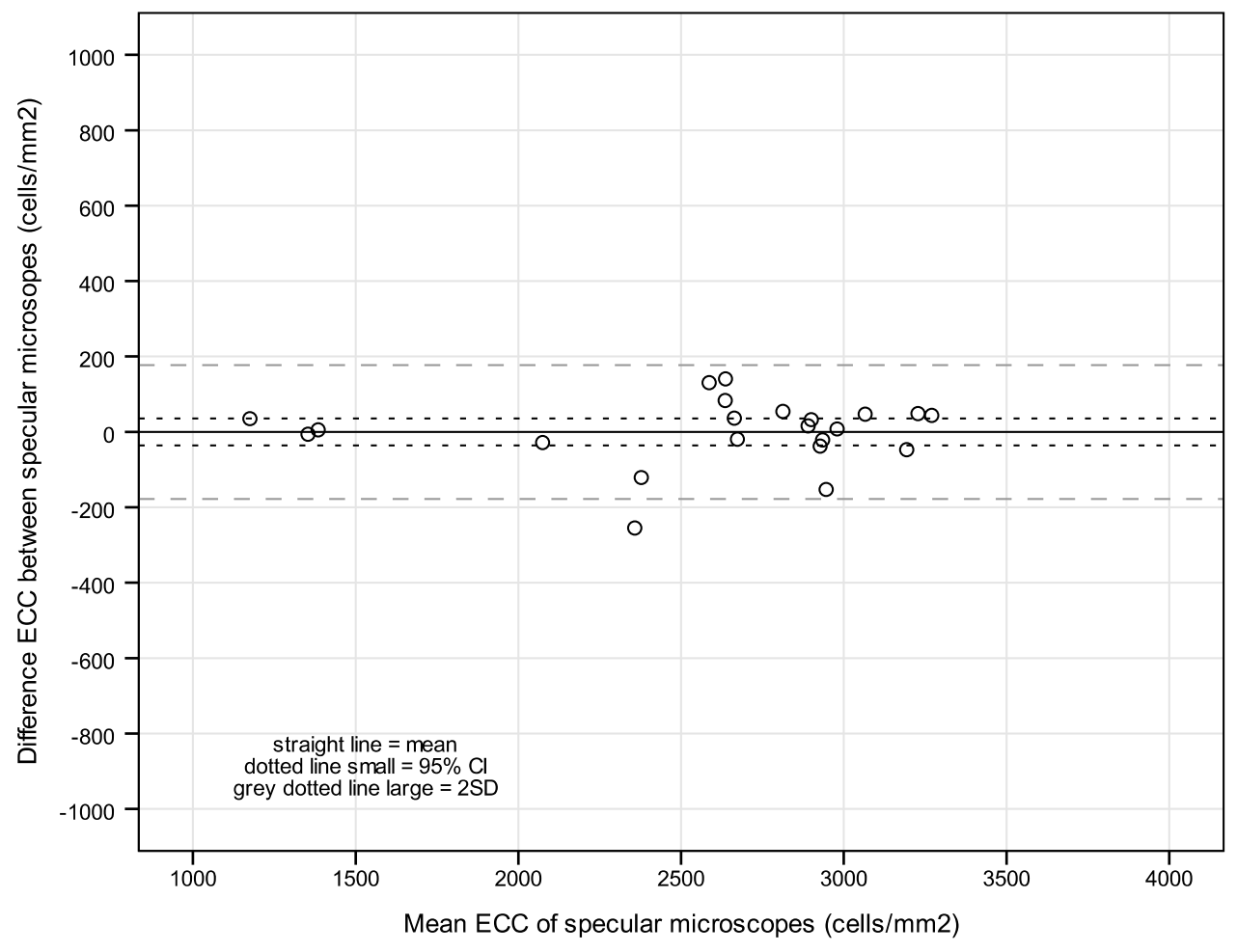

Figure 5 Bland-Altman plot of endothelial cell count after external calibration. 
Table 3 Difference in Endothelial Cell Count per Specular Microscope After External Calibration Correction

\begin{tabular}{|l|l|l|}
\hline $\begin{array}{l}\text { Specular } \\
\text { Microscope }\end{array}$ & $\begin{array}{l}\text { Mean ECC } \\
\left(\text { Cells } / \mathbf{m m}^{2}\right)\end{array}$ & $\begin{array}{l}\text { Difference }\left(\text { Cells } / \mathbf{m m}^{2}\right) \\
\text { (SD) }(\mathbf{p})\end{array}$ \\
\hline $\begin{array}{l}\text { SP-2000P } \\
\text { SP-3000P }\end{array}$ & 2593.6 & $0.4($ SD 88.7) $(\mathrm{P}=0.98)$ \\
\hline
\end{tabular}

Abbreviations: ECC, endothelial cell count; SD, standard deviation; $p$, significance level linear mixed model.

our case was caused by software imprecision and erroneous calibration.

We solved this problem by 1) checking and, where necessary, correcting the magnification settings in both instruments and in the analysis software, 2) re-checking the magnification, using an external (micro-)calibration tool, and 3) calculating a correction factor so that the ECC results obtained with both instruments from the same eyes no longer showed a systematic difference.
Accurate and reliable endothelial cell analysis is not easy to perform. Known reasons for imprecise measurement are known to be (1) the accuracy of operator-software interaction, (2) software precision, (3) specular reflection limitations leading to the generation of a low-quality image, (4) versatility for acquiring endothelial mosaic images, and (5) sampling processes. ${ }^{17}$ Even when one technician is responsible for acquiring and analyzing an endothelial cell image, $a \pm 2-$ $5 \%$ variability is described. ${ }^{18}$ The quality of the acquired image largely determines the accuracy of the analysis. ${ }^{19}$ Identifying cell borders in a specular micrograph can be difficult, and poor recognition of cell borders can result in the erroneous omission of cells or double entry of cells during analysis. Omitting one single cell during analysis can lead to errors ranging from $0.5 \%$ to $1.1 \%$, depending on the size of the omitted cell and cell density per surface area. ${ }^{18}$ We aimed to avoid these possible errors by having one

\section{SP-2000P}

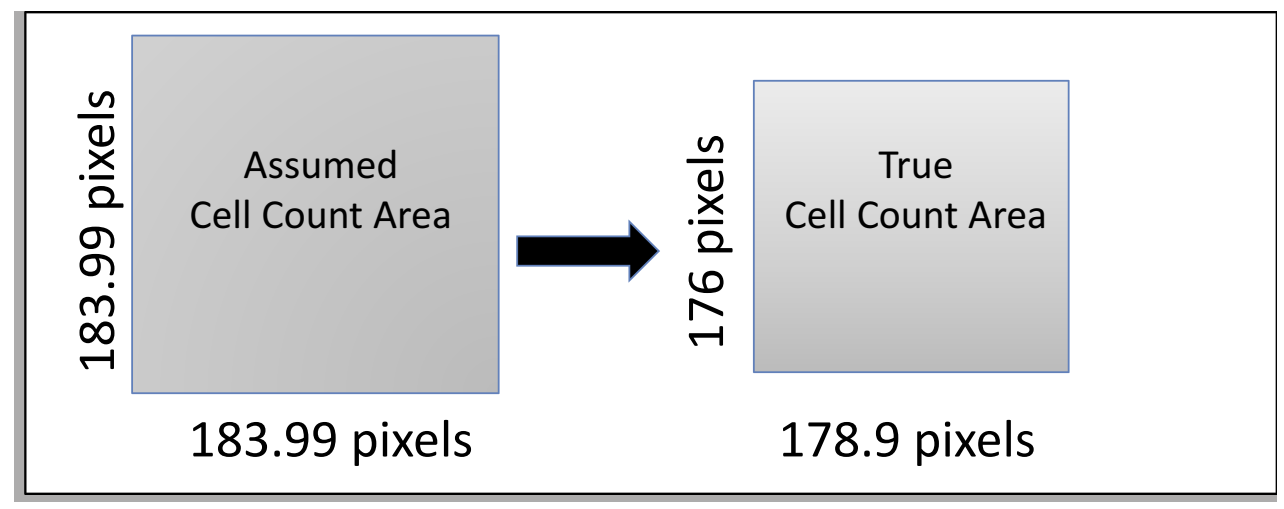

\section{SP-3000P}

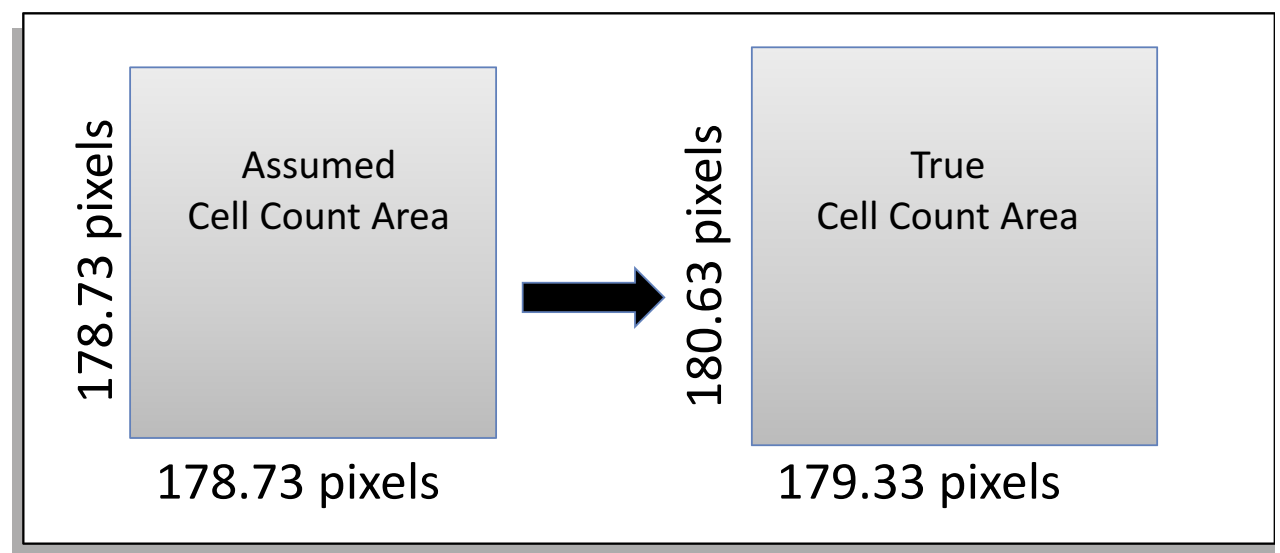

Figure 6 Based on external calibration, a difference in "true cell count area" versus "assumed cell count area" was found. Moreover, a slight asymmetric distortion of the postulated square surface area was noted. A correction factor was calculated, based on the difference in surface area. 


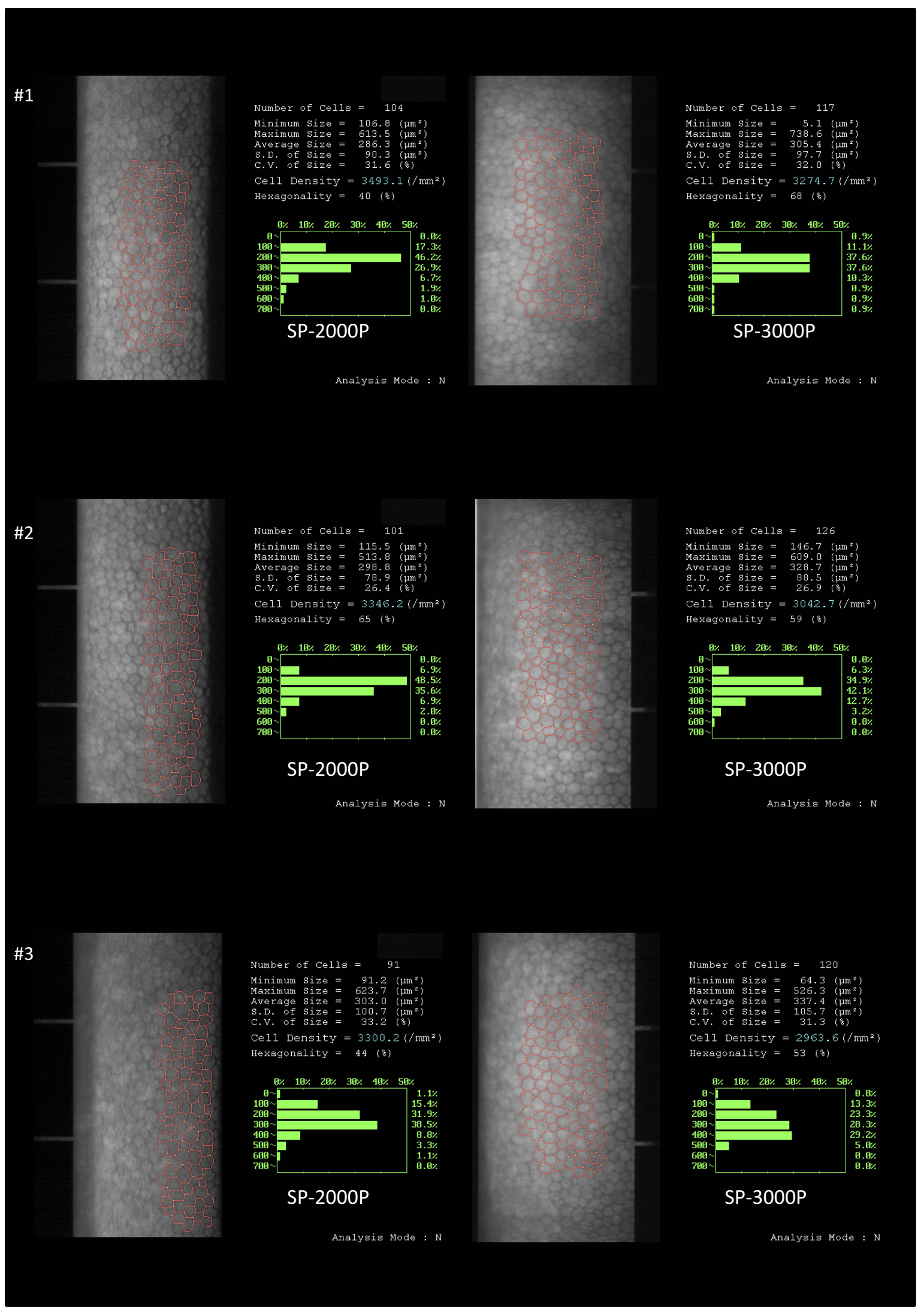

Figure 7 Endothelial cell photographs showing a systematic difference in endothelial cell count between the Topcon SP-2000P corneal specular microscope (left) and the Topcon SP-3000 corneal specular microscope (right). 


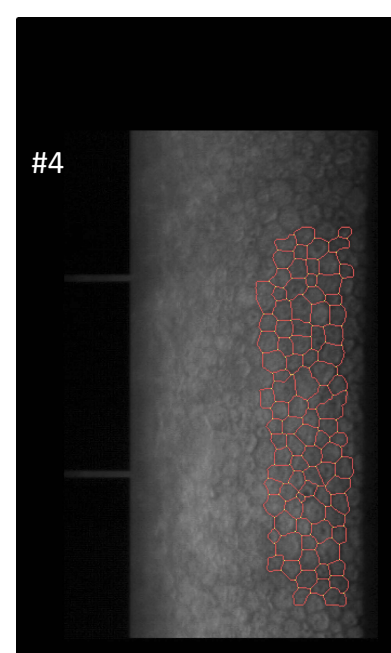

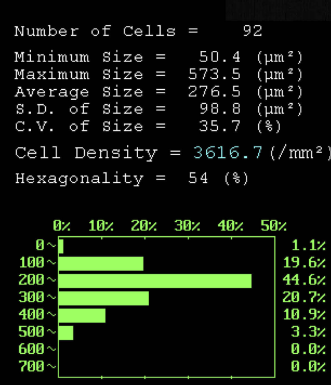

SP-2000P
Number of Cells $=99$ Minimum Size $=108.3\left(\mu^{2}\right)$ Average size $=310.4\left(\mu^{2}\right)$ S.D. of size $=113.2\left(\mu \mathrm{m}^{2}\right)$
C.V. of size $=36.5\left(\frac{\mathrm{o}}{8}\right)$ Cell Density $=3221.6\left(/ \mathrm{mm}^{2}\right)$ Hexagonality $=55\left(\frac{\circ}{\%}\right)$

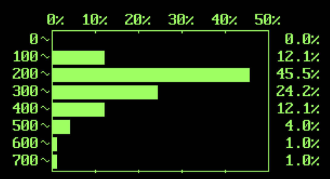

SP-3000P

Number of Cells $=72$ Minimum Size $=124.4\left(\mu^{2}\right)$ Average size $=406.8\left(\mathrm{\mu m}^{2}\right)$ S.D. of Size $=140.7\left(\mu^{2}{ }^{2}\right.$
C.V. of Size $=34.6\left(\frac{\%}{8}\right)$ Cell Density $=2458.3\left(/ \mathrm{mm}^{2}\right)$ Hexagonality $=58\left(\frac{8}{8}\right)$

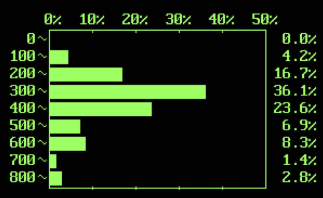

SP-2000P

Analysis Mode : $\mathrm{N}$

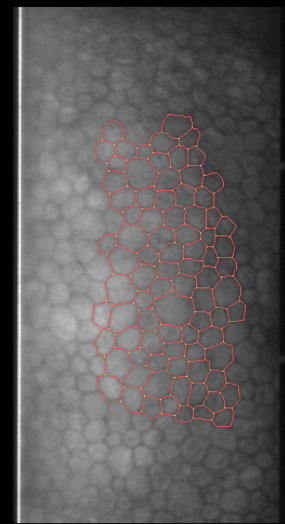

Number of Cells $=84$ $\begin{aligned} \text { Minimum Size }=201.8\left(\mu^{2}\right) & 201.8 \\ \text { Maximum Size } & =1164.7\left(\mu^{2}{ }^{2}\right)\end{aligned}$ Average size $=445.5\left(\mu^{2}\right)$

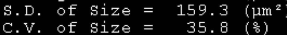
Cell Density $=2244.8\left(/ \mathrm{mm}^{2}\right)$ Hexagonality $=70\left(\frac{8}{8}\right)$

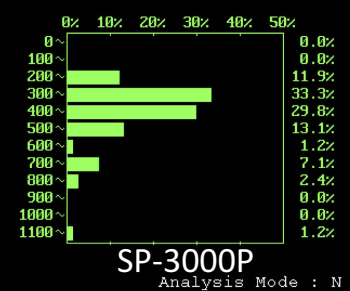

\#6

Number of Cells $=73$ Minimum Size $=150.8\left({\left.\mu \mathrm{m}^{2}\right)}^{2}\right)$
Maximum Size $=622.8\left(\mu^{2}\right)$ Average Size $=391.4\left({\mu \mathrm{m}^{2}}^{2}\right)$ S.D. of Size $=106.9\left(\mu^{2}\right)$
C.V. of Size $=27.3\left(\frac{\mathrm{g}}{8}\right)$

Cell Density $=2554.8\left(/ \mathrm{mm}^{2}\right.$ Hexagonality $=58\left(\frac{\circ}{8}\right)$

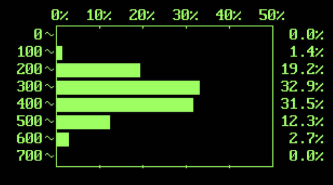

SP-2000P

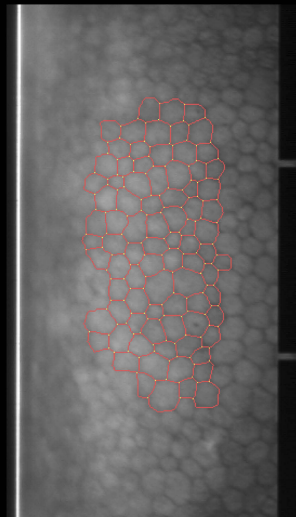

Number of Cells $=83$ Minimum Size $=192.2\left(\mu^{2}\right)$ Average size $\left.=441.4\left(\mu^{2}\right)^{2}\right)$ S.D. of $\mathrm{size}=138.4\left(\mathrm{\mu m}^{2}\right)$
C.V. of size $=31.4\left(\frac{\mathrm{o}}{8}\right)$ Cell Density $=2265.3\left(/ \mathrm{mm}^{2}\right)$ Hexagonality $=61\left(\frac{\%}{8}\right)$

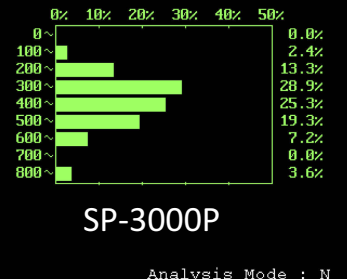

Analysis Mode : N

Figure 7 (Continued) 
experienced operator generating and analyzing the consecutively acquired images.

The reliability of the evaluation of the corneal endothelium seems to be a recurrent topic for discussion. $^{3-8,14,16}$ Software imprecisions within the TopCon SP series have been previously described by Cheung and Cho. They found significant differences in ECC of the SP2000P from the semi-automated ECC IMAGEnet counts compared to the re-traced ECC. They recommend that re-traced analysis is necessary. ${ }^{13}$ We also noticed that the semi-automated border recognition was not optimal with both the SP-2000P and SP$3000 \mathrm{P}$, thus accordingly, we adjusted cell borders using the re-traced method. Attempts to optimise cell border recognition are ongoing. ${ }^{20}$ Regarding software-instrument accuracy, Van Schaik et al report unchecked preset factory values, leading to substantial errors in ECC of up to $9 \%$ with the SP2000P and IMAGEnet2000 software. $^{14}$ We discovered an identical situation with our CSM and associated IMAGEnet software, where we encountered multiple (inaccurate) magnification values. Unfortunately, we were unable to determine the reason for these. We hypothesize that software updates might have been the cause. But even after re-tracing endothelial cell borders and adjustment of the settings with correct magnification factors, the two CSMs continued to show a significant difference in ECC. An asymmetric distortion in the photographs taken was revealed by external horizontal and vertical calibration. This distortion in the EC counting area resulted in an underestimation in ECC of 1.4\% in the SP-3000P and an overestimation in ECC of $8.1 \%$ in the SP-2000P. To the best of our best knowledge, this distortion in the image is a matter that has not previously been described in the literature. After creating a correction factor for the over- or underestimation in the cell count area, the two CSMs showed no significant difference in EC counts. External calibration seems to be the only way to correct this distortion.

We propose a method for improving interchangeability concerns when using different CSMs and to continue obtaining precise endothelial cell counts when a CSM needs to be replaced. The method we describe for externally calibrating our specular microscope is not restricted to the Topcon specular microscopes and can be directly applied to other specular or confocal microscopes and their associated analysis software packages. We advise to implement these steps prior to using an
CSM and its software, especially in multicenter trials or long prospective studies where the corneal endothelium is a key safety outcome measure. It is noteworthy, however, that retrospective correction of interchangeability issues with ECCs is possible.

\section{Acknowledgments}

We would like to thank Henry Claessens and Pierre Gelissen from Topcon Europe for their expertise and kind assistance.

\section{Disclosure}

Gwyneth A van Rijn and Gregorius PM Luyten report grants from Ophthec BV, grants from Stichting Blindenhulp, grants from Uitzicht: ANVVB, LSBS, during the conduct of the study. The authors report no other conflicts of interest in this work.

\section{References}

1. Laing RA, Sandstrom MM, Leibowitz HM. Clinical specular microscopy. I. Optical principles. Arch Ophthalmol. 1979;97(9):17141719. doi:10.1001/archopht.1979.01020020282021

2. Vogt A. Die Sichtbarkeit des lebenden Hornhautendothels. Albrecht Von Graefes Archiv Für Ophthalmologie. 1920;101(2):123-144. doi:10.1007/BF02004299

3. Garza-Leon M. Corneal endothelial cell analysis using two noncontact specular microscopes in healthy subjects. Int Ophthalmol. 2016;36(4):453-461. doi:10.1007/s10792-015-0133-z

4. Maruoka S, Nakakura S, Matsuo N, et al. Comparison of semiautomated center-dot and fully automated endothelial cell analyses from specular microscopy images. Int Ophthalmol. 2018;38(6):24952507. doi:10.1007/s10792-017-0760-7

5. Gasser L, Reinhard T, Bohringer D. Comparison of corneal endothelial cell measurements by two non-contact specular microscopes. BMC Ophthalmol. 2015;15:87. doi:10.1186/s12886-015-0068-1

6. Goldich Y, Marcovich AL, Barkana Y, et al. Comparison of corneal endothelial cell density estimated with 2 noncontact specular microscopes. Eur $J$ Ophthalmol. 2010;20(5):825-830. doi:10.1177/ 112067211002000503

7. de Sanctis U, Machetta F, Razzano L, Dalmasso P, Grignolo FM. Corneal endothelium evaluation with 2 noncontact specular microscopes and their semiautomated methods of analysis. Cornea. 2006;25(5):501-506. doi:10.1097/01.ico.0000214217.83119.af

8. Cakici O, Karadag R, Bayramlar H, Koyun E. Measurements of central corneal thickness and endothelial parameters with three different non-contact specular microscopy devices. Int Ophthalmol. 2017;37(1):229-233. doi:10.1007/s10792-016-0264-x

9. Tan AN, Webers CA, Berendschot TT, et al. Corneal endothelial cell loss after Baerveldt glaucoma drainage device implantation in the anterior chamber. Acta Ophthalmol. 2017;95(1):91-96. doi:10.1111/aos.13161

10. Hirooka K, Nitta E, Ukegawa K, Sato S, Kiuchi Y. Effect of trabeculectomy on corneal endothelial cell loss. Br J Ophthalmol. 2019. doi:10.1136/bjophthalmol-2018-313417

11. Jonker SMR, Berendschot T, Ronden AE, Saelens IEY, Bauer NJC, Nuijts R. Long-term endothelial cell loss in patients with artisan myopia and artisan toric phakic intraocular lenses: 5- and 10-year results. Ophthalmology. 2018;125(4):486-494. doi:10.1016/j.ophtha.2017.08.011 
12. Saxena R, Landesz M, Noordzij B, Luyten GPM. Three-year followup of the Artisan phakic intraocular lens for hypermetropia. Ophthalmology. 2003;110(7):1391-1395. doi:10.1016/S0161-6420 (03)00405-6

13. Cheung SW, Cho P. Endothelial cells analysis with the TOPCON specular microscope SP-2000P and IMAGEnet system. Curr Eye Res. 2000;21(4):788-798. doi:10.1076/ceyr.21.4.788.5548

14. van Schaick W, van Dooren BT, Mulder PG, Volker-Dieben HJ. Validity of endothelial cell analysis methods and recommendations for calibration in Topcon SP-2000P specular microscopy. Cornea. 2005;24(5):538-544. doi:10.1097/01.ico.0000151505.03824.6c

15. Ding X, Huang Q, Zheng Y, Jiang Y, Huang S, He M. Measurement area and repeatability of semiautomated assessment of corneal endothelium in the Topcon specular microscope SP-2000P and IMAGEnet system. Cornea. 2012;31(10):1111-1118. doi:10.1097/ICO.0b013e31820e42b5

16. Luft N, Hirnschall N, Schuschitz S, Draschl P, Findl O. Comparison of 4 specular microscopes in healthy eyes and eyes with cornea guttata or corneal grafts. Cornea. 2015;34(4):381-386. doi:10.1097/ ICO. 0000000000000385
17. Abib FC, Holzchuh R, Schaefer A, Schaefer T, Godois R. The endothelial sample size analysis in corneal specular microscopy clinical examinations. Cornea. 2012;31(5):546-550. doi:10.1097/ICO. 0b013e3181cc7961

18. McCarey BE, Edelhauser HF, Lynn MJ. Review of corneal endothelial specular microscopy for FDA clinical trials of refractive procedures, surgical devices, and new intraocular drugs and solutions. Cornea. 2008;27(1):1-16. doi:10.1097/ICO.0b013e31815892da

19. Lass JH, Gal RL, Ruedy KJ, et al. An evaluation of image quality and accuracy of eye bank measurement of donor cornea endothelial cell density in the specular microscopy ancillary study. Ophthalmology. 2005;112(3):431-440.

20. Piorkowski A, Nurzynska K, Gronkowska-Serafin J, Selig B, Boldak $\mathrm{C}$, Reska D. Influence of applied corneal endothelium image segmentation techniques on the clinical parameters. Comput Med Imaging Graph. 2017;55:13-27. doi:10.1016/j.compmedimag.2016.07.010
Clinical Ophthalmology

\section{Publish your work in this journal}

Clinical Ophthalmology is an international, peer-reviewed journal covering all subspecialties within ophthalmology. Key topics include: Optometry; Visual science; Pharmacology and drug therapy in eye diseases; Basic Sciences; Primary and Secondary eye care; Patient Safety and Quality of Care Improvements. This journal is indexed on PubMed

\section{Dovepress}

Central and CAS, and is the official journal of The Society of Clinical Ophthalmology (SCO). The manuscript management system is completely online and includes a very quick and fair peer-review system, which is all easy to use. Visit http://www.dovepress.com/ testimonials.php to read real quotes from published authors. 